\title{
INTRODUCTION
}

\section{The Stories of Liliana Heker}

In 1966, the twenty-three-year-old Argentinian writer Liliana Heker won the prestigious Casa de las Américas prize with a collection of short stories, Los que vieron la zarza (Those who saw the burning bush). The book was published in Buenos Aires, in July of that same year, by Jorge Alvarez, an editor whose keen eye had led him to discover such future luminaries as Manuel Puig and Rodolfo Walsh. A few days earlier, in June, the weak democratic government of President Arturo Illia had been overturned by a military coup led by General Juan Carlos Onganía. Onganía was an antiliberal ultraconservative who quickly dismantled the workers' unions and tried to place the universities under his own authority. The attack on professors and students, effected less than a month after the coup, came to be known as the "Night of the Long Sticks" because of the brutality of the assault. Paradoxically, this repression sparked a vigorous opposition to the government which would, years later, force the military leaders to call for democratic elections.

At the time, Liliana Heker, besides writing short stories, was working as subeditor of El Escarabajo de Oro (The gold-bug), a celebrated literary magazine she had founded in 1961 with the 
writer Abelardo Castillo. Clearly left-wing but interested, above all, in publishing good literature, the magazine continued to appear until 1974, and throughout Onganía's dictatorship, it maintained the same ideological and literary position it had before the coup. El Escarabajo de Oro became the centre of vigorous debates, explicitly opposing censorship and acts of violence, defending the Cuban Revolution and Third World movements and offering a platform to some of the most distinguished contemporary writers.

Later, during the bloodiest era of Argentinian history, Heker's position of resisting in situ and taking active part in the public debate did not change. In 1976, as a result of another coup, General Jorge Rafael Videla became the new head of government, and under his authority tens of thousands of men, women and children were arrested, tortured and killed or forced into exile. Hundreds of babies born to so-called terrorist women in military prisons were taken away and sold or given to families close to the regime. To justify his actions, Videla explained that "a terrorist is not only someone who carries a bomb or a gun, but also someone who spreads ideas contrary to Western and Christian civilisation."

To write under a dictatorship is, unfortunately, an all too common experience in the history of our literatures. Those who oppose a tyrant are all too often either imprisoned, killed or exiled, even though the authorities never realize that such measures, however drastic, never quite succeed in silencing a writer. The words of Ovid in exile, Boethius in prison, and Isaac Babel murdered continue to resonate for us, their readers, today. As Heker wrote at the time: 'Censorship is never infallible . . It is the advances made by a writer against the limits imposed on him, and 
not a fatalistic acceptance of those limits, that change the cultural history of a country, and therefore history itself.'

Heker, true to this conviction, and faced with the option of exile, chose to stay in Buenos Aires. The strategies of survival under these circumstances are complex and mysterious, and owe much to chance; they have to be reinvented day after day. In a few cases, they turn out to be successful, and both the writer and the work manage to outlive the oppression. 'My fiction writing,' she later explained, 'didn't change at all during the military dictatorship. A novel, a short story, are always elaborate constructions and they are meant to last; in the small space of freedom that your own room conquers, you can work on a piece with a bare heart and give in to the most scandalous or audacious ideas. I will give a personal example: during the first years of the last military dictatorship, in the midst of its horror, fear and threats of death, I kept on working on a short novel about an alcoholic man and his wife that I had started sometime before the coup. This passionate and meticulous writing, this diving into my characters' intimate nightmares, rescued me, during my working hours, from the external nightmare, and it allowed me to be carried away, through the adventure of creation, from the constraining world.'

To follow her policy of what she called 'cultural resistance,' besides leading underground writers' workshops and signing petitions in favour of the Mothers of Plaza de Mayo, towards the end of 1977 , at the height of the military dictatorship, and again with Abelardo Castillo, Heker founded a new literary magazine, El Ornitorrinco (The platypus), whose motto was taken from Oscar Wilde: 'One should always be a little improbable.' The magazine 
published Argentinian authors silenced by the regime, as well as foreign ones who could not find a home in more orthodox publications. Among the subjects debated in El Ornitorrinco were the defence of human rights, the themes of censorship and self-censorship, the absurd possibility of a war with Chile (promoted by both Videla and Pinochet) and other questions related to the role of the intellectual in a climate of terror, including the differences between writing in exile and writing from home. In this latter debate, Julio Cortázar, who had been living in Paris since the fifties, defended the exile's choice as the only possible one to maintain a testimonial presence and bear witness of the abuses back home; Heker countered with a long letter defending the position of the writer who chooses to stay and fight on home ground. "We are neither heroes nor martyrs,' she wrote to Cortázar, who was a friend. 'One can be a traitor abroad or at home. One can have a national perspective from the vantage point of exile, or write in an ivory tower in one's own country. What a writer has done, what a writer does with his words, that is in the end the only valid question.'

What Heker does with her words is never political in a superficial or dogmatic sense, and yet her world is firmly grounded in the reality of her place and time. The Dutch author Cees Nooteboom once suggested that a writer has ultimately only a handful of themes at his or her disposal. 'There's hunger,' he said, 'there's death, there's illness, there's war. But everything, from the writer's point of view, is political.' Nooteboom used 'political' in its etymological sense: belonging to the polis, to the society in which the writer writes. Heker accepts Nooteboom's connotation of politi- 
cal: her characters are steeped in the Argentinian ethos or, rather, in the ethos of Buenos Aires, and in its particular emotional geography, which Jorge Luis Borges so poignantly charted in the thirties and forties.

After Borges received international recognition, it seemed impossible for any Argentinian writer to avoid falling under his enormous shadow. The novelist Manuel Mujica Lainez became so tired with the devotion the younger generation showed towards Borges that he composed a short poem entitled "To a Young Writer."

It's useless for you to foster

All hope of forging ahead

Because however much you scribble

Borges will have been there first.

Heker carefully avoided the obvious paths that Borges had laid out. The master's fantastic themes, his abhorrence of psychological and sociological portraits, his labyrinths, his games with time and space, never became features of her literary landscape. She admired, of course, Borges' craft and knew, like all those who came after him, that she wrote in a Spanish that had been cleansed and made more efficiently rigorous by Borges, but her interest lay in other things.

Over the years, Heker published a book of essays, Las hermanas de Shakespeare (Shakespeare's daughters), and two widely acclaimed novels, Zona de clivaje (Cleavage zone) and El fin de la historia, the latter translated into English by Andrea Labinger 
as The End of the Story. But even though these are notable accomplishments, it is in the short story that she achieves a kind of unique perfection.

Heker's central theme is the family and its responses to the encroaching world. Also, the curious rituals that couples, adults and children, and siblings among themselves, invent to relate to one another, rituals that, at the same time, help them find their singular identities. The consequences of tiny acts may be enormous ("Now") or ineffable ("The Night of the Comet"). They may distil the creative life to a handful of experiences ("Early Beginnings or Ars Poetica") or portray a future life in a single all-encompassing relationship ("Jocasta"). They may entail the loss of everything we take for granted ("The Cruelty of Life") or everything we might hope for ("The Music of Sundays"). They may stem from a quasisoap opera atmosphere ("Family Life") or from lives of quiet desperation ("Georgina Requeni or the Chosen One"). They may lead to vast existential questions ("Bishop Berkeley or Mariana of the Universe") or to infinitesimal epiphanies ("Strategies Against Sleep”). In every case, Heker's stories raise the quotidian to the literary status of an epic. Her characters face minute dilemmas with the wholeheartedness and courage of knights errant, as if they realized that possible solutions to our greatest sorrows can sometimes be discerned in the undergrowth of private heartbreaks and the tangle of intimate losses, in secret paths that may lead away from the traps of private violence, alcoholism, betrayal of love, familiar misunderstandings. A certain Hasidic belief in the microcosm reflecting the macrocosm underlies Heker's conception of the universe. 
One of Heker's best-known stories, gathered in countless anthologies, is "The Stolen Party." The careful building-up of a child's expectation at a birthday party that lies implacably beyond her unnamed borders, mirrors, on a miniature scale, the partitions and prohibitions of society as a whole. Everything can be played out as normal, but one tiny misplaced gesture is bound to shatter the entire social structure. Nothing is said, but the outstretched hand of the 'lady of the house' in the last paragraph, poised in the conventional action of giving, becomes all of a sudden its shadow, the hand of a society that robs children and denies them their right to equality.

Commenting on the craft of the short story, the Irish writer William Trevor said: 'I think it is the art of the glimpse. If the novel is like an intricate Renaissance painting, the short story is an Impressionist painting. It should be an explosion of truth.' When the explosion has taken place and the dust has settled, the reader of Heker's stories is aware that something has been revealed, and that now the world seems both stranger and clearer than before, and feels grateful for the modest miracle.

Alberto Manguel 
This page intentionally left blank 